\title{
KONSUMSI BAHAN MAKANAN SUMBER KARBOHIDRAT DAN BUAH INDEKS GLIKEMIK TINGGI DENGAN KEJADIAN DM
}

\author{
Kasmiyetti, Dian Febry Yomi \\ (Poltekkes Kemenkes Padang)
}

\begin{abstract}
Diabetes Mellitus occupy as the fourth largest cause of death in Padang. Based on data from Puskemas Nanggalo Padang in 2013, there were 1.012 people (2.7\%) who suffered from diabetes mellitus. The glycemix index is defined as the level of food according to their effect on blood sugar levels. The aim of this research was to determine the relationship of consumption food sources of carbohydrates and fruit high glycemic index of diabetes mellitus tipe II outpatients in Puskesmas Nanggalo Padang in 2016. Using cross sectional design, the participants of this research were taken with accidental sampling method, as may as 50 peoples. Data of patients were collected through interviews, while the consumption patterns measure by using the Form Food Frequency (FFQ). The statistical test used is chi-square test with 95\% confidence level. The results of analysis there are significant correlation between consumption food sources of high-glycemic carbohydrate with the incidence of diabetes mellitus tipe II, there are no significant correlation between consumption food sources of high-glycemic fruit with the incidence of diabetes mellitus.Based on the results, the health center was suggested to provide a nutrition counseling of glycemic index and refer diabetes patients to a dietitian for get an education about dietary management to reduce the incidence of diabetes mellitus.
\end{abstract}

Keywords: Diabetes Mellitus, Carbohydrat ,High Glycemic Index Fruit

\begin{abstract}
Abstrak
Diabetes Mellitus menempati peringkat empat besar penyebab kematian di Padang. Data Puskesmas Nanggalo Padang diperoleh pasien diabetes mellitus tahun 2013 sebanyak 1012 orang $(2,7 \%)$. Indeks glikemik diartikan sebagai tingkatan pangan menurut efeknya terhadap kadar gula darah. Penelitian ini bertujuan mengetahui hubungan pola konsumsi bahan makanan sumber karbohidrat dan buah indeks glikemik tinggi dengan kejadian diabetes mellitus tipe II di Puskesmas Nanggalo Kota Padang tahun 2016. Menggunakan desain cross sectional, sampel diambil dengan accidental sampling, sebanyak 50 orang . Data dari sampel dikumpulkan melalui wawancara, sedangkan data pola konsumsi dengan menggunakan form Food Frequency (FFQ). Uji statistik yang digunakan adalah uji chisquare dengan tingkat kepercayaan 95\%. Hasil analisa menunjukkan ada hubungan yang bermakna antara pola konsumsi bahan makanan sumber karbohidrat indeks glikemik tinggi dengan kejadian diabetes mellitus tipe II, tidak terdapat hubungan yang bermakna antara pola konsumsi bahan makanan sumber buah indeks glikemik tinggi dengan kejadian diabetes mellitus. Berdasarkan hasil penelitian, disarankan kepada pihak Puskesmas untuk memberikan penyuluhan gizi kepada masyarakat terkait indeks glikemik dan merujuk pasien diabetes ke ahli gizi untuk mendapatkan pendidikan tentang manajemen diet untuk mengurangi kejadian diabetes mellitus.
\end{abstract}

Kata kunci : Diabetes Mellitus, Karbohidrat, Buah Indeks Glikemik Tinggi

Penerbit: Poltekkes Kemenkes Padang, http://jurnal.poltekkespadang.ac.id/ojs/index.php/jsm 


\section{PENDAHULUAN}

Diabetes melitus (DM) merupakan penyakit kronis yang masih menjadi masalah utama dalam dunia kesehatan di Indonesia. Menurut American Diabetes Association (ADA), ${ }^{1}$ diabetes mellitus adalah suatu kelompok penyakit metabolik dengan karakteristik hiperglikemia yang terjadi karena kelainan sekresi insulin, kerja insulin atau kedua-duanya.

Berdasarkan data Riset Kesehatan Dasar (Riskesdas) tahun 2013, ${ }^{2}$ penyakit diabetes mellitus menduduki peringkat keenam sebagai penyebab kematian pada kategori penyakit tidak menular. Diabetes melitus merupakan penyakit endokrin yang paling umum ditemukan. Penyakit ini ditandai oleh hiperglikemia dan glikosuria. ${ }^{3}$

Indeks glikemik diartikan sebagai tingkatan pangan menurut efeknya terhadap kadar gula darah. ${ }^{4}$ Penelitian yang dilakukan oleh Rinnelya $(2013)^{5}$ menyatakan bahwa indeks glikemik ialah angka yang menunjukkan potensi peningkatan kadar glukosa darah dari karbohidrat yang tersedia pada suatu makanan. Makanan yang mempunyai indeks glikemik tinggi bila dikonsumsi akan meningkatkan kadar glukosa dalam darah dengan cepat dalam jumlah yang tinggi. Heather,dkk (2001) ${ }^{6}$ menyatakan bahwa pangan dengan indeks glikemik rendah dapat memperbaiki pengendalian metabolik pada penderita diabetes tipe 2 dewasa. Sementara penelitian metaanalisa yang dilakukan oleh Miller,dkk. (2003) ${ }^{7}$ menyatakan pasien diabetes yang mengkonsumsi diet indeks glikemik rendah mengalami penurunan kadar $\mathrm{HbA1c}$.

Buah merupakan pangan penting yang dapat menjadi sumber karbohidrat, vitamin, mineral, serat, dan senyawa fenolat yang berfungsi sebagai antioksidan. Sejumlah studi epidemiologi menunjukkan bahwa tingginya konsumsi buah berkorelasi negatif dengan risiko penyakit-penyakit kardiovaskular, kanker, dan kronis seperti obesitas dan diabetes. Pengaruh konsumsi pangan berkarbohidrat, termasuk buah, terhadap kadar glukosa darah yang juga disebut respon glikemik, saat ini telah menjadi isu penting, baik untuk pasien diabetes mellitus (diabetesi), pra-diabetes, maupun orang sehat, khususnya dalam memilih jenis, bentuk asupan, dan jumlah karbohidrat ataupun buah yang dikonsumsi. ${ }^{8}$

Sebagian pasien diabetes tidak mau mengkonsumsi buah karena beranggapan bahwa rasa manis pada buah berhubungan langsung dengan peningkatan kadar gula darah. Padahal belum tentu demikian, mengingat respon glikemik buah ditentukan oleh sejumlah faktor, seperti jenis gula yang dikandungnya dan sifat-sifat intrinsik yang berkaitan dengan pelepasan gula (sugar release properties) dari buah tersebut.

Organisasi Kesehatan Dunia (WHO) pada September 2012 menjelaskan bahwa, ${ }^{10}$ penyakit diabetes menempati posisi keempat yang merupakan risiko kematian terbesar di dunia dengan jumlah penderita di dunia mencapai 347 juta orang dan lebih dari $80 \%$ kematian akibat diabetes mellitus terjadi pada negara miskin dan berkembang. Hasil studi Penerbit: Poltekkes Kemenkes Padang, http://jurnal.poltekkespadang.ac.id/ojs/index.php/jsm 
dari International Diabetes Federation (IDF) pada 2012 mengungkapkan, ${ }^{11}$ Indonesia menduduki urutan ketujuh dengan penderita diabetes terbanyak. dengan jumlah penderita sebanyak 7,6 juta orang. Laporan hasil Riskesdas tahun $2013,{ }^{2}$ menunjukkan peningkatan prevalensi diabetes mellitus dari 1,1 persen (2007) menjadi 2,4 persen (2013).

Diabetes mellitus menempati posisi keempat penyebab kematian setelah Ketuan/lansia, jantung dan hipertensi di Kota Padang pada Tahun 2013. ${ }^{12}$ Data dari Puskesmas Nanggalo Padang diperoleh pasien penderita diabetes mellitus pada tahun 2012 sebanyak 778 orang dan pada tahun 2013 meningkat menjadi 1012 orang (2,7\%). ${ }^{13}$ Berdasarakan pengamatan awal di wilayah puskesmas Nanggalo, untuk konsumsi karbohidrat dengan indeks glikemik tinggi masih cukup tinggi, dan untuk konsumsi buah, dengan keadaan geografis dan cuaca di Sumatera Barat yang panas, buah yang banyak dikonsumsi adalah buah dengan kandungan air yang tinggi, seperti semangka ( indeks glikemik tinggi).

Berdasarkan hal tersebut maka penulis tertarik untuk meneliti Pola Konsumsi Bahan Makanan Sumber Karbohidrat dan Buah Indeks Glikemik Tinggi dengan Kejadian Diabetes Mellitus Tipe II.

\section{METODE PENELITIAN}

Penelitian ini bersifat analitik dengan desain cross sectional study, dilakukan di Puskesmas Nanggalo Kota Padang tahun 2016. Populasi dalam penelitian ini adalah seluruh pengunjung Puskesmas Nanggalo yang berusia 45-65 tahun. Pengambilan responden engan metode accidental sampling, jumlah responden sebanyak 50 orang.

Data yang dikumpulkan meliputi data pasien yang terdiagnosa diabetes mellitus tipe II, dikumpulkan melalui wawancara, Sedangkan data pola konsumsi bahan makanan sumber karbohidrat dan buah indeks glikemik tinggi didapatkan melalui pengukuran pola konsumsi dengan menggunakan FFQ.

Analisis data meliputi analisis univariat dan bivariat. Untuk melihat hubungan antara variabel independen dan dependen digunakan uji chi square.

\section{HASIL PENELITIAN}

Gambaran umum responden menunjukkan bahwa sebagian besar pasien (66 \%) berumur antara 55-65 tahun, sebagian besar pasien berjenis kelamin perempuan (62 \%), sebagian besar pasien adalah ibu rumah tangga (42\%).

\section{Pola Konsumsi Karbohidrat Indeks Glikemik Tinggi}

Frekuensi Pasien Berdasarkan Penyakit Diabetes Tipe II Pada saat dilakukan penelitian pasien yang terdiagnosa Diabetes Mellitus sebanyak 26 orang (52\%).

Penerbit: Poltekkes Kemenkes Padang, http://jurnal.poltekkespadang.ac.id/ojs/index.php/jsm 
Tabel 1.Distribusi Frekuensi Pasien Berdasarkan Diagnosa Penyakit Diabetes

Mellitus Tipe II

\begin{tabular}{ccc}
\hline Penyakit Diabetes & $\mathrm{n}$ & $\%$ \\
\hline Terdiagnosa & $\mathbf{2 6}$ & 52 \\
\hline Tidak Terdiagnosa & $\mathbf{2 4}$ & 48 \\
\hline Total & $\mathbf{5 0}$ & 100
\end{tabular}

\section{Pola Konsumsi Buah Indeks Glikemik Tinggi}

Pasien mengkonsumsi buah indeks glikemik tinggi dengan kategori jarang sebanyak 34 orang $(68 \%)$.

Tabel 3. Distribusi Frekuensi Pasien Berdasarkan Pola Konsumsi Buah Indeks Glikemik Tinggi.

\begin{tabular}{ccc}
\hline Penyakit Diabetes & $\mathrm{n}$ & $\%$ \\
\hline Sering & 16 & 32 \\
\hline Jarang & 34 & 68 \\
\hline Total & 50 & 100
\end{tabular}

\section{Hubungan Pola Konsumsi Karbohidrat Indeks Glikemik Tinggi dengan Kejadian}

\section{Diabetes Mellitus Tipe II}

Pasien yang terdiagnosa diabetes mellitus tipe II lebih banyak (96\%) sering mengkonsumsi karbohidrat indeks glikemik tinggi dibandingkan dengan kategori jarang $(8 \%)$.

Tabel 4. Pola Konsumsi Karbohidrat Indeks Glikemik Tinggi dengan Kejadian Diabetes Mellitus Tipe II

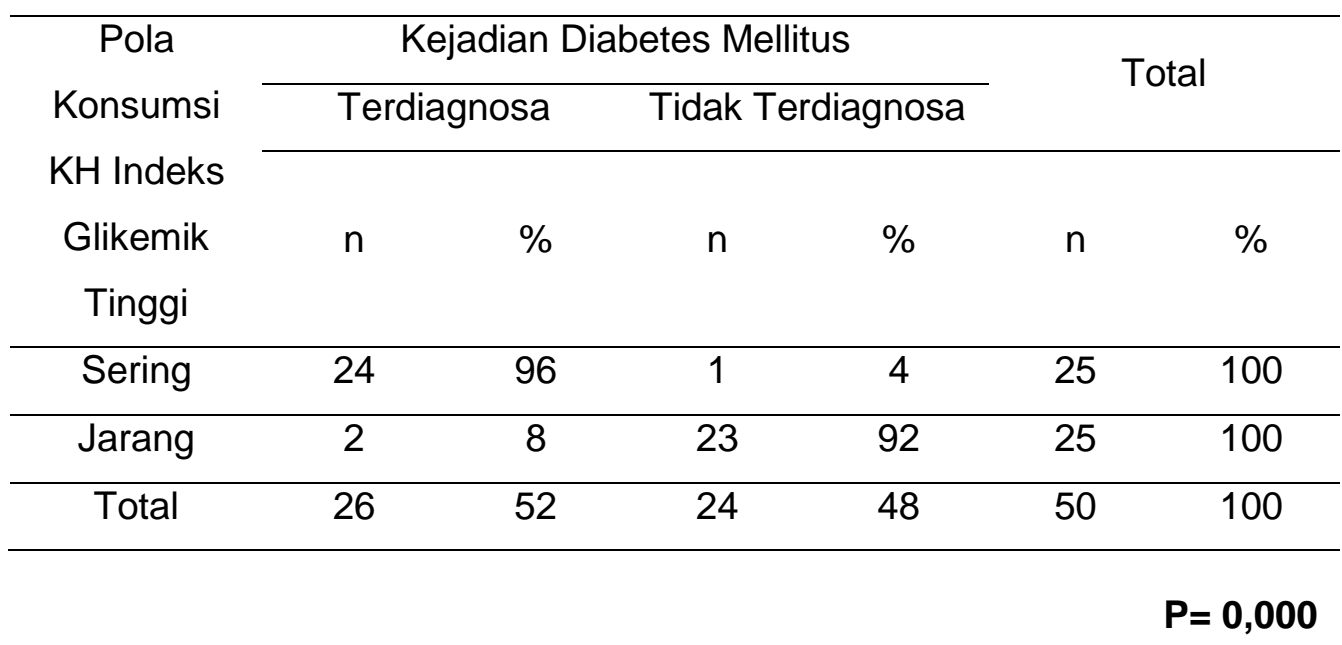


Hasil uji statistik dengan menggunakan uji chi-square dengan melihat hasil Fisher's Exact Test didapatkan nilai $p=0,000$ berarti pada $(p<0,05)$, artinya ada hubungan yang bermakna antara pola konsumsi bahan makanan sumber karbohidrat indeks glikemik tinggi dengan kejadian diabetes mellitus tipe II.

Hubungan Pola Konsumsi Buah Indeks Glikemik Tinggi dengan Kejadian Diabetes Mellitus Tipe II

Pasien yang terdiagnosa diabetes mellitus tipe II lebih banyak $(68,8 \%)$ sering mengkonsumsi buah indeks glikemik tinggi dibandingkan dengan kategori jarang $(44,1 \%)$.

Tabel 5. Pola Konsumsi Buah Indeks Glikemik Tinggi dengan Kejadian

Diabetes Mellitus Tipe II

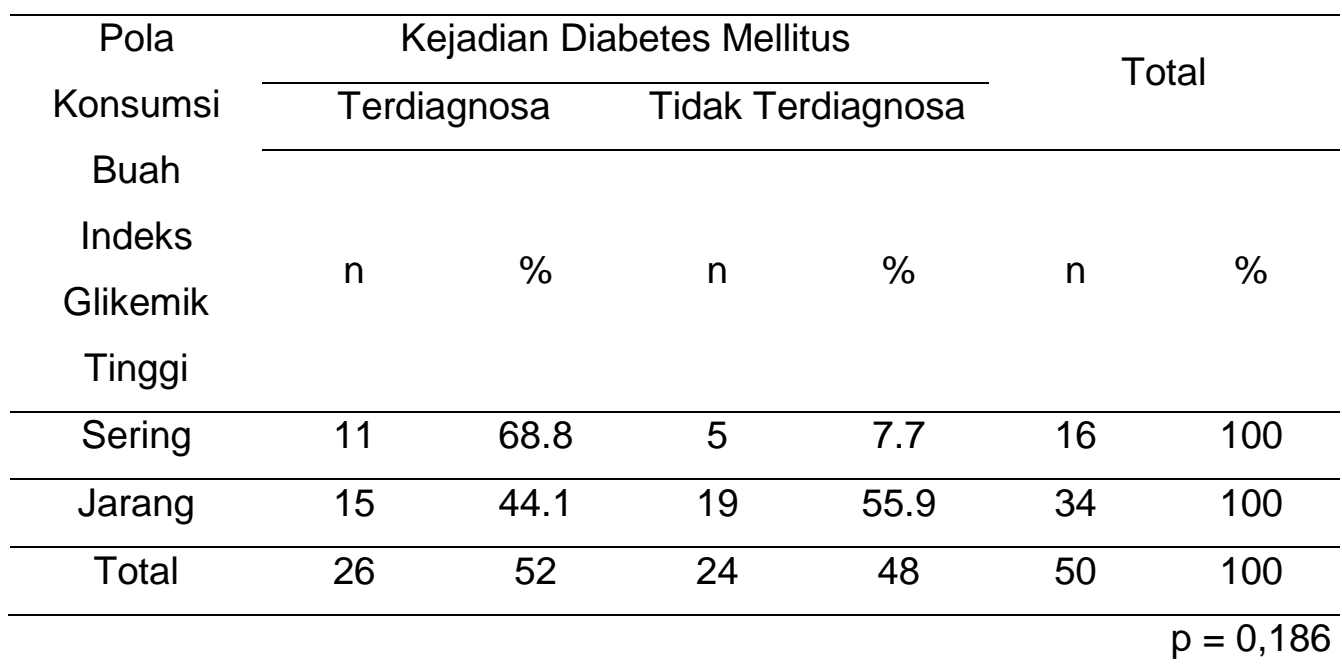

Hasil uji statistik dengan menggunakan uji chi-square, dengan melihat hasil Continuity Correction, didapatkan nilai $p=0,186$ berarti pada ( $p>0,05)$, artinya tidak ada hubungan yang bermakna antara pola konsumsi bahan makanan sumber buah indeks glikemik tinggi dengan kejadian diabetes mellitus.

\section{PEMBAHASAN}

\section{Pola Konsumsi Karbohidrat Indeks Glikemik Tinggi dengan Kejadian Diabetes Mellitus Tipe II}

Mengkonsumsi karbohidrat indeks glikemik tinggi maksimal 2 kali sehari, semakin sering mengkonsumsinya akan menaikkan kadar gula darah sehingga kadar gula darah tidak dapat terkontrol pada tingkat yang aman. ${ }^{4}$ 
Hasil uji statistik didapat ada hubungan yang bermakna antara pola konsumsi bahan makanan sumber karbohidrat indeks glikemik tinggi dengan kejadian diabetes mellitus tipe II.

Secara teori, pada penderita diabetes, fakta dari penelitian jangka menengah menunjukkan bahwa penggantian karbohidrat yang memiliki indeks glikemik tinggi dengan pangan yang memiliki indeks glikemik rendah akan memperbaiki pengendalian glikemik. Sementara pada kelompok yang memperoleh pengobatan dengan insulin akan menurunkan episode hipoglikemik.

Penelitian yang dilakukan oleh Rinnelya (2013) menyatakan bahwa indeks glikemik ialah angka yang menunjukkan potensi peningkatan kadar glukosa darah dari karbohidrat yang tersedia pada suatu makanan. Makanan yang mempunyai indeks glikemik tinggi bila dikonsumsi akan meningkatkan kadar glukosa dalam darah dengan cepat dalam jumlah yang tinggi. ${ }^{4,5} \mathrm{Hal}$ ini serupa dengan hasil penelitian yang dilakukan oleh peneliti sendiri bahwa dengan sering ( $>2 x$ sehari) mengkonsumsi bahan makanan dengan indeks glikemik tinggi maka akan meningkatkan kadar gula darah dan menyebabkan Diabetes Mellitus sehingga ada hubungan antara pola konsumsi bahan makanan sumber karbohidrat indeks glikemik tinggi dengan kejadian diabetes mellitus.

Bahan makanan sumber karbohidrat indeks glikemik tinggi yang rata-rata dikonsumsi pasien saat penelitian adalah roti, beras giling, bihun kering, sereal biskuit, roti kering dengan pengembang, wafer, wortel, kentang dan singkong.Pada teorinya, banyak pangan berkarbohidrat (roti, kentang, dan berbagai jenis beras) dicerna dan diserap sangat cepat. Karbohidrat dalam pangan yang dipecah dengan cepat selama pencernaan memiliki indeks glikemik tinggi. Respon gula darah terhadap jenis pangan (karbohidrat) ini cepat dan tinggi. Dengan kata lain, glukosa dalam aliran darah meningkat dengan cepat. ${ }^{4}$

Pada saat penelitian, sebagian besar tidak mengetahui mengenai indeks glikemik makanan serta hubungannya dengan kejadian diabetes mellitus.

\section{Pola Konsumsi Buah Indeks Glikemik Tinggi dengan Kejadian Diabetes Mellitus Tipe II}

Pada teorinya, beberapa jenis buah mempunyai indeks glikemik tinggi. Apabila sering mengkonsumsi buah indeks glikemik tinggi maka akan mempengaruhi kenaikan kadar gula darah dengan cepat.

Hasil uji statistik tidak ada hubungan yang bermakna antara pola konsumsi bahan makanan sumber buah indeks glikemik tinggi dengan kejadian diabetes mellitus tipe II, dimana terdapat kecenderungan terdiagnosa diabetes mellitus dengan sering mengkonsumsi buah indeks glikemik tinggi.

Penerbit: Poltekkes Kemenkes Padang, http://jurnal.poltekkespadang.ac.id/ojs/index.php/jsm 
Pengaruh konsumsi pangan berkarbohidrat, termasuk buah, terhadap kadar glukosa darah yang juga disebut respon glikemik, dengan mengkonsumsi buah dengan indeks glikemik tinggi dapat meningkatkan kadar gula darah, sehingga harus diperhatikan dalam memilih jenis, bentuk asupan, dan jumlah karbohidrat ataupun buah yang dikonsumsi. ${ }^{6}$ Sementara menurut Miller,dkk. (1991), studi pemberian jangka menengah pangan dengan indeks glikemik rendah pada penderita diabetes menunjukkan bahwa pangan dengan indeks glikemik rendah berhubungan dengan peningkatan pengendalian gula darah. ${ }^{4}$

Pada teorinya pola konsumsi buah dengan indeks glikemik tinggi dan kejadian diabetes mellitus memiliki hubungan, karena bahan makanan dengan indeks glikemik tinggi dapat meningkatkan kadar gula darah pasien. Namun pada penelitian ini tidak ditemukan hubungan, hal ini mungkin dapat disebabkan karena konsumsi bahan makanan sumber buah yang ditanyakan dalam penelitian hanya beberapa kali dikonsumsi oleh responden hal ini sangat mempengaruhi hasil FFQ untuk pola konsumsi bahan makanan sumber buah. Buah yang sering dikonsumsi pasien pada saat penelitian adalah semangka dan sukun serta beberapa pasien mengkonsumsi buah kaleng dan kismis. Hal lain yang mungkin juga berpengaruh yaitu responden memang jarang mengkonsumsi buah, baik dengan indeks glikemik tinggi maupun dengan indeks glikemik rendah.

Pada teorinya, bahan makanan yang dipecah dengan cepat selama pencernaan memiliki Indeks Glikemik tinggi. Respon gula darah terhadap jenis pangan (karbohidrar) ini cepat dan tinggi. Dengan kata lain, glukosa dalam aliran darah meningkat dengan cepat. Peningkatan kadar gula darah yang cepat akan menaikkan kebutuhan insulin. Selama insulin dapat mengimbangi, peningkatan kadar gula darah dalam jangka pendek tidak menjadi masalah. Namun bila peningkatan ini berlangsung lama, insulin tidak mampu lagi menjaga kadar gula darah pada taraf normal. Toleransi tubuh terhadap glukosa darah menurun dan akhirnya timbul penyakit diabetes mellitus.

\section{SIMPULAN DAN SARAN}

Terdapat hubungan yang bermakna antara pola konsumsi bahan makanan sumber karbohidrat indeks glikemik tinggi dengan kejadian Diabetes Mellitus tipe II.Diharapkan penderita DM dapat melakukan pengecekan gula darah secara berkala, untuk mengatasi dan mencegah terjadinya diabetes mellitus. Kepada pihak Puskesmas untuk dapat memberikan penyuluhan kepada masyarakat tentang indekglikemik, sehingga masyarakat dapat memilih makanan dengan indeks glikemik rendah. 


\section{DAFTAR KEPUSTAKAAN}

1. Indonesia. Jakarta: PERKENI; 2013.

2. Departemen Kesehatan Republik Indonesia. Hasil Riset Kesehatan Dasar. Jakarta: Badan Penelitian dan Pengembangan Kesehatan, Departemen Kesehatan Republik Indonesia; 2013.

3. Budiyanto, MAK. Gizi dan Kesehatan. Jakarta: UMM Press; 2002.

4. Rimbawan dan Albiner S. Indeks Glikemik Pangan, Cara Mudah Memilih Pangan yang Menyehatkan. Jakarta : Penebar Swadaya; 2004.

5. Rinnelya A. Efek Hiperglikemia Postpradial Terhadap Kemampuan Memori Jangka Pendek Pada Pasien Diabete Mellitus Tipe 2 Di Puskesmas Cipondoh Tangerang [Tesis]. Depok: Universitas Indonesia; 2013.

6. Heather,dkk. Didalam Rimbawan dan Albiner S. Indeks Glikemik Pangan, Cara Mudah Memilih Pangan yang Menyehatkan. Jakarta : Penebar Swadaya; 2004. h. 65-68

7. Hoerudin. Indeks Glikemik buah dan implikasinya dalam pengendalian kadar glukosa darah [skripsi]. Bogor: Balai Besar Penelitian dan Pengambangan Pascapanen Pertanian; 2012.

8. Waspadji S, dkk. Indeks Glikemik Berbagai Makanan Indonesia Hasil Penelitian. Jakarta: Balai Penerbit Fakultas Kedokteran Universitas Indonesia; 2003.

9. WHO. Diabetes [serial online] (dikutip 08 September 2014). Tersedia dari: URL: http://www.who.int/medicentre/fact-sheets/fs312/en/

10. Kementerian Kesehatan Republik Indonesia. Diabetes melitus penyebab kematian nomor 6 di dunia : Kemenkes tawarkan solusi cerdik melalui posbind. Rilis Berita [serial online] 2013 September (dikutip 8 November 2014). Tersedia dari: URL: http://www.depkes.go.id/

11. Laporan Dinas Kesehatan Kota (DKK) Padang. 2013.

12. Laporan Kesehatan Puskesmas Nanggalo Kota Padang. 2013.

13. Utami P dan Tim Tentera. Terapi jus diabetes mellitus. Jakarta: PT. Agromedia Pustaka; 2004.

14. Irianto K. Epidemiologi penyakit menular dan tidak menular panduan klinis. Bandung: ALFABETA, cv; 2014. 